\title{
INFORMED CONSENT DALAM PELAYANAN KESEHATAN
}

\author{
A driana Pakendek \\ (D osen Fakultas H ukum U niversitas M adura Pamekasan, \\ email:adri.pakendek@gmail.com)
}

\begin{abstract}
A bstract:
It is a must to apply the informed consent in public health service, particularly in a hosptal. As a matter of fact, some medical patients or the representative does not comprehend the term informed consent due to the ineffective communication between the patient and physician. Whereas, a doctor should have a legal informed consent to execute medical action from the patient, otherwise she/ he would experience a question of law; private and punitive law as well as indisciplinary punishment. A petient is able to deny an informed consent, yet it is identified as an informed refusal. However, the patient must be responsible for any medical impacts in the future. In this case, a doctor is free from any legal actions as the result of consent refusal of patient.
\end{abstract}

\section{Key Words:}

informed consent, pasien dan dokter

\section{Pendahuluan}

Seringkali kita mendengar dari orang-orang yang berhubungan dengan pelayanan kesehatan terutama di rumah sakit, pernah disodori secarik kertas dari petugas untuk ditandatangai, kata petugas untuk persetujuan tindakan, apakah dioperasi, di-SC, atau lainnya. Sebelum penandatangan persetujuan tindakan didahului dengan penyampaian informasi oleh petugas yang berkompoten kepada pasien atau pihak suami/ isteri atau orang tua pasien tentang tindakan yang akan dilakukan dan kemungkinan komplikasi bila terjadi. Prosedur demikian sudah baku, masalah kadang muncul di saat pasien atau suami/ isteri atau orangtua pasien merasa ada 
A driana Pakendek

ketidakwajaran di saat tindakan atau setelah tindakan operasi, misalnya pasien tidak sadar-sadar (koma). Lalu pihak pasien menanyakannya yang kemudian mendapatkan jawaban yang tidak memuaskan. Di sinilah 'sengketa' mulai muncul.

Menurut Loebby Loqman' informed consent belum menyelesaikan permasalahan yang terjadi dalam praktek. Dengan kata lain meskipun di dalam praktek selalu dilakukan memberikan informasi kepada pasien tentang apa yang akan dilakukan oleh seorang dokter, dan juga dimintakan persetujuan pasien atas apa yang akan dilakukan oleh seorang dokter, tetap terjadi perselisihan pendapat apabila terjadi suatu peristiwa yang tidak diharapkan.

Penyampaian informasi untuk melakukan tindakan medis lazim dikenal dengan istilah 'informed consent'. Pelaksanaan informed consent tidak hanya mengikuti protap (prosedur tetap) tetapi sesungguhnya mempunyai pertanggungjawaban hukum.

Undang-Undang Kesehatan yang lama (UUK No 23 Tahun 1992), Informed consent tidak tercantum secara khusus. Kita hanya dapat melihat dan disinggung sedikit bahwa dalam keadaan darurat dimana dibutuhkan tindakan medis maka hanya dapat dilakukan dengan persetujuan ibu hamil yang bersangkutan atau suami atau keluarganya (pasal 15 ayat 2 huruf c).

Undang-Undang Kesehatan yang baru (UUK No. 36 Tahun 2009), informed consent (menggunakan istilah bukan informed consent) sudah lebih banyak disinggung. Misalnya pada pasal 8 yang berbunyi, "Setiap orang berhak memperoleh informasi tentang data kesehatan dirinya termasuk tindakan dan pengobatan yang telah maupun yang akan diterimanya dari tenaga kesehatan".

Selanjutnya pasal 56 ayat 1 berbunyi: "Setiap orang berhak menerima atau menolak sebagian atau seluruh tindakan pertolongan yang akan diberikan kepadanya setelah menerima dan memahami informasi mengenai tindakan tersebut secara lengkap".

1Loebby Loqman, T injauan Hukum Pidana Terhadap Hubungan Tenaga Kesehatan dengan Konsumen/Pasien, Konsultasi Hukum yang Berkaitan dengan Pelayanan Kesehatan di Rumah Sakit, (Surabaya, 2000), hlm. 2 
I nformed Consent

Persetujuan Tindakan Kedokteran atau Kedokteran Gigi diatur juga dalam Undang-Undang No 29 Tahun 2009 Tentang Praktek Kedokteran, pada paragraf 2 pasal 45 ayat (1) sampai (6).

Bagaimana pelaksanaan informed consent itu? Apa aspek hukumnya? Melalui tulisan ini akan dibahas tentang Informed consent dalam Pelayanan Kesehatan.

\section{Pengertian Informed Consent}

Dalam berkas rekam medis pasien di rumah sakit terdapat satu lembaran yaitu lembar persetujuan tindakan medis. Lembaran ini akan diisi/ diberi persetujuan oleh pasien atau keluarganya apabila telah mendapat penjelasan dari tenaga kesehatan. Proses pemberian penjelasan ini disebut sebagai informed consent.

Istilah Informed consent dalam Undang-Undang Kesehatan kita tidak ada, yang tercantum adalah istilah persetujuan, menerima atau menolak ... tindakan pertolongan setelah menerima dan memahami informasi mengenai tindakan tersebut.

Informed consent atau persetujuan Medik/Informed consent adalah persetujuan yang diberikan oleh pasien sesuai dengan pasal 1 (a) Permenkes RI Nomor 585/MEN.KES/ PER/ X/ 1989 2. Di mana pasal 1 (a) menyatakan bahwa persetujuan tindakan medik (informed consent) adalah persetujuan yang diberikan oleh pasien atau keluarganya atas dasar penjelasan mengenai tindakan medik yang akan dilakukan terhadap pasien tersebut. Informed consent mencakup peraturan yang mengatur perilaku dokter dalam berinteraksi dengan pasien. Interaksi tersebut melahirkan suatu hubungan yang disebut hubungan dokter-pasien.

Informed consent secara harfiah terdiri dari dua kata yaitu informed dan consent. Informed berarti telah mendapat penjelasan atau informasi; sedangkan consent berarti memberi persetujuan atau mengizinkan. Dengan demikian informed consent berarti suatu persetujuan yang diberikan setelah mendapat informasi ${ }^{3}$. A tau dapat

2 Siswanto Pabidang, "Pentingnya Informed Consent", Tabloid BIDI, (10 September 2004), hlm. 3

3 Husein Kerbala, Segi-segi Etis dan Yuridis Informed Consent, Jakarta: Pustaka Sinar Harapan, 2000), hlm. 57 
A driana Pakendek

juga dikatakan informed consent adalah pernyataan setuju dari pasien yang diberikan dengan bebas dan rasional, sesudah mendapatkan informasi dari dokter dan sudah dimengerti olehnya ${ }^{4}$.

Istilah informed consent menurut KKI 5 adalah Persetujuan Tindakan Kedokteran atau Kedokteran Gigi yang mempunyai arti persetujuan pasien atau yang sah mewakilinya atas rencana tindakan kedokteran atau kedokteran gigi yang diajukan oleh dokter atau dokter gigi, setelah menerima informasi yang cukup untuk dapat membuat persetujuan. Persetujuan tindakan kedokteran atau kedokteran gigi adalah pernyataan sepihak dari pasien dan bukan perjanjian antara pasien_dengan dokter atau dokter gigi, sehingga dapat ditarik kembali setiap saat. Persetujuan tindakan kedokteran atau kedokteran gigi merupakan proses sekaligus hasil dari suatu komunikasi yang efektif antara pasien dengan dokter atau dokter gigi, dan bukan sekedar penandatanganan formulir persetujuan.

Persetujuan tindakan kedokteran adalah pernyataan sepihak pasien atau yang sah mewakilinya yang isinya berupa persetujuan atas rencana tindakan kedokteran atau kedokteran gigi yang diajukan oleh dokter atau dokter gigi, setelah menerima informasi yang cukup untuk dapat membuat persetujuan atau penolakan. Suatu persetujuan dianggap sah apabila: (1)Pasien telah diberi penjelasan/ informasi; (2) Pasien atau yang sah mewakilinya dalam keadaan cakap (kompeten) untuk memberikan keputusan/ persetujuan; (3) Persetujuan harus diberikan secara sukarela.

\section{Bentuk-bentuk Informed consent}

Ada dua bentuk Informed consent yaitu: (1) dengan pernyataan (expression), dapat secara lisan (oral) dan secara tertulis (written); (2) dianggap diberikan, tersirat (implied) yaitu dalam keadaan biasa atau normal dan dalam keadaan gawat darurat.

4J. Guwandi, Informed Consent \& Informed R efusal, (Jakarta: Fak. Kedokteran UI, 2006), hlm. 1

5 Konsil Kedokteran Indonesia, Manual Persetujuan Tindakan Kedokteran, Jakarta: Konsil Kedokteran Indonesia, 2006), hlm. 1 
Expressed consent adalah persetujuan yang dinyatakan secara lisan atau tulisan, bila yang akan dilakukan lebih dari prosedur pemeriksaan dan tindakan yang biasa. Sebaiknya pasien diberikan pengertian terlebih dahulu tindakan apa yang akan dilakukan. Misalnya, pemeriksaan dalam lewat anus atau dubur atau pemeriksaan dalam vagina, dan lain-lain yang melebihi prosedur pemeriksaan dan tindakan umum. Di sini belum diperlukan pernyataan tertulis, cukup dengan persetujuan secara lisan saja. Namun bila tindakan yang akan dilakukan mengandung resiko tinggi seperti tindakan pembedahan atau prosedur pemeriksaan dan pengobatan invasif, harus dilakukan secara tertulis.

Implied consent adalah persetujuan yang diberikan pasien secara tersirat, tanpa pernyataan tegas. Isyarat persetujuan ini ditangkap dokter dari sikap pasien pada waktu dokter melakukan tindakan, misalnya pengambilan darah untuk pemeriksaan laboratorium, pemberian suntikan pada pasien, penjahitan luka dan sebagainya. Implied consent berlaku pada tindakan yang biasa dilakukan atau sudah diketahui umum.

Pendapat Mertokusumo, menyebutkan bahwa informed consent dari pasien dapat dilakukan dengan cara antara lain 6: (1) dengan bahasa yang sempurna dan tertulis; (2) dengan bahasa sempurna secara lisan; (3) dengan bahasa yang tidak sempurna asal dapat diterima oleh pihak lawan; (4) dengan bahasa isyarat asal dapat diterima oleh pihak lawan; (5) dengan diam atau membisu tetapi asal dipahami atau diterima oleh pihak lawan.

Pernyataan IDI tentang informed consent yang tertuang dalam Surat Keputusan PB IDI No 319/ PB/ A4/ 88 adalah:

1. Manusia dewasa sehat jasmani dan rohani berhak sepenuhnya menentukan apa yang hendak dilakukan terhadap tubuhnya. Dokter tidak berhak melakukan tindakan medis yang bertentangan dengan kemauan pasien, walaupun untuk kepentingan pasien sendiri.

6 Anny Isfandyarie, M alpraktek dan R esiko M edik dalam Kajian Hukum Pidana, Jakarta: Prestasi Pustaka Publisher, 2005), hlm. 58 
2. Semua tindakan medis (diagnotik, terapeutik maupun paliatif) memerlukan informed consent secara lisan maupun tertulis.

3. Setiap tindakan medis yang mempunyai risiko cukup besar, mengharuskan adanya persetujuan tertulis yang ditandatangani pasien, setelah sebelumnya pasien memperoleh informasi yang adekuat tentang perlunya tindakan medis yang bersangkutan serta risikonya.

4. Untuk tindakan yang tidak termasuk dalam butir 3, hanya dibutuhkan persetujuan lisan atau sikap diam.

5. Informasi tentang tindakan medis harus diberikan kepada pasien, baik diminta maupun tidak diminta oleh pasien. Menahan informasi tidak boleh, kecuali bila dokter menilai bahwa informasi tersebut dapat merugikan kepentingan kesehatan pasien. Dalam hal ni dokter dapat memberikan informasi kepada keluarga terdekat pasien. Dalam memberi informasi kepada keluarga terdekat dengan pasien, kehadiran seorang perawat/ paramedik lain sebagai saksi adalah penting.

6. Isi informasi mencakup keuntungan dan kerugian tindakan medis yang direncanakan, baik diagnostik, terapeutik maupun paliatif. Informasi biasanya diberikan secara lisan, tetapi dapat pula secara tertulis (berkaitan dengan informed consent).

\section{Keharusan M embuat Informed Consent}

A pakah Informed consent harus dibuat? Karena dalam suatu tindakan diperlukan persetujuan maka sudah menjadi keharusan bagi dokter atau sarana kesehatan untuk selalu membuat Informed consent. Apalagi berkas rekam medis menyediakan satu lembar sebagai lembar persetujuan tindakan medis.

Keharusan adanya informed consent secara tertulis yang ditandatangani oleh pasien sebelum dilakukannya tindakan medik dilakukan di sarana kesehatan seperti rumah sakit atau klinik karena erat kaitannya dengan pendokumentasiannya ke dalam catatan medik (medical record). Dengan demikian, rumah sakit turut bertanggungjawab apabila tidak terpenuhinya persyaratan informed consent, maka dokter yang bersangkutan dapat dikenakan sanksi 
Informed Consent

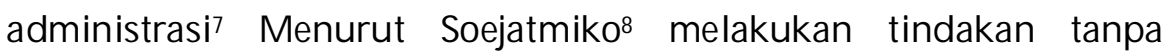
disertai persetujuan tindakan medik merupakan salah satu keadaan yang dapat menyebabkan terjadinya tuntutan malpraktek pidana karena kecerobohan.

Informed consent baru diakui bila pasien telah mendapatkan informasi yang jelas tentang tindakan medis yang akan dilakukan terhadap dirinya. Dalam pemberian informasi ini, dokter berkewajiban untuk mengungkapkan dan menjelaskan kepada pasien dalam bahasa sesederhana mungkin sifat penyakitnya, sifat pengobatan yang disarankan, alternatif pengobatan, kemungkinan berhasil dan resiko yang dapat timbul serta komplikasi-komplikasi yang tak dapat diubah.

Pasien dapat saja menolak memberikan persetujuan setelah diberikan informasi melalui informed consent, penolakan tersebut dikenal dengan istilah informed refusal. Hal ini dapat dibenarkan berdasarkan hak asasi seseorang untuk menentukan apa yang hendak dilakukan terhadap dirinya. Untuk informed refusal maka pasien harus memahami segala konsekuensi yang akan terjadi pada dirinya yang mungkin timbul akibat penolakan tersebut dan tentunya dokternya tidak dapat dipersalahkan akibat karena penolakan tersebut. Untuk penolakan tersebut maka dilakukan penandatangan oleh pasien pada lembar Penolakan Tindakan Kedokteran.

\section{Informed Consent sebagai Bukti Tertulis}

Meskipun hanya selembar kertas tetapi Iembar Informed consent yang telah ditandatangani dapat dijadikan bukti di pengadilan apabila terjadi tuntutan hukum di kemudian hari. Sehubungan dengan itu, salah satu cara yang dilakukan untuk melindungi kepentingan dokter terhadap tuntutan pasien, maka di dalam bentuk informed consent secara tertulis dicantumkan syarat bahwa dokter tidak akan dituntut di kemudian hari. Syarat yang dimaksud adalah pasien menyadari sepenuhnya atas segala resiko tindakan medik

7 Veronika Komalawati, Peranan Informed Consent dalam Transaksi Terapeutik Suatu Tinjauan Yuridis, Persetujuan dalam Hubungan Dokter dan Pasien, (Bandung: Citra Aditya Bakti, 1999), hlm. 180

8 Isfandyarie, M al praktek dan R esiko, hlm. 57 
yang akan dilakukan dokter, dan jika dalam tindakan medik itu terjadi sesuatu yang tidak diinginkan, maka pasien tidak akan mengadakan tuntutan apapun ke pengadilan di kemudian hari 9.

Seiring dengan perkembangan informed consent, kelengkapan berkas administrasi rumah sakit semakin disediakan seperti: Surat Pernyataan Persetujuan Pengobatan, Surat Pernyataan Persetujuan Operasi dan Anastesi, Surat Pernyataan Dirawat di Unit Khusus, dan sebagainya. Menurut Appelbaum untuk menjadi doktrin hukum, maka Informed consent harus memenuhi syarat, sebagai berikut: (1) Adanya kewajiban dari dokter untuk menjelaskan informasi kepada pasien; (2) Adanya kewajiban dari dokter untuk mendapatkan izin atau persetujuan dari pasien, sebelum dilaksanakan perawatan.

Informed consent termasuk bidang Hukum Kedokteran, sebagai cabang IImu Hukum, sehingga Hukum Kedokteran pun harus mengikuti sistematik IImu Hukum secara umum ${ }^{10}$. Di dalam IImu Hukum dikenal tiga macam sanksi yaitu sanksi Administratif, sanksi Perdata (ganti kerugian), dan sanksi Pidana (hukum badan, denda). Dan masih ada sanksi di bidang Etik dan Disiplin yang termasuk wewenang organisasi profesi secara intern yang tidak dicampuri oleh hukum.

Jika seorang dokter tidak memperoleh persetujuan tindakan kedokteran yang sah, maka dampaknya adalah bahwa dokter tersebut akan dapat mengalami masalah 11:

1. Hukum Pidana

Menyentuh atau melakukan tindakan terhadap pasien tanpa persetujuan dapat dikategorikan sebagai "penyerangan" (assault). Hal tersebut dapat menjadi alasan pasien untuk mengadukan dokter ke penyidik polisi, meskipun kasus semacam ini sangat jarang terjadi.

2. Hukum Perdata

Untuk mengajukan tuntutan atau klaim ganti rugi terhadap dokter, maka pasien harus dapat menunjukkan bahwa dia tidak diperingatkan sebelumnya mengenai hasil akhir tertentu dari

${ }^{9}$ Komalawati, Peranan Informed C onsent, , hlm. 172

${ }^{10}$ Guwandi, Informed Consent dan Informed R efusal, hlm. 34

11 Konsil Kedokteran Indonesia, M anual Persetujuan Tindakan Kedokteran , hIm. 3 
tindakan dimaksud padahal apabila dia telah diperingatkan sebelumnya maka dia tentu tidak akan mau menjalaninya, atau menunjukkan bahwa dokter telah melakukan tindakan tanpa persetujuan (perbuatan melanggar hukum).

3. Pendisiplinan oleh MKDKI

Bila MKDKI menerima pengaduan tentang seorang dokter atau dokter gigi yang melakukan hal tersebut, maka MKDKI akan menyidangkannya dan dapat memberikan sanksi disiplin kedokteran, yang dapat berupa teguran hingga rekomendasi pencabutan Surat Tanda Registrasi.

\section{Penutup}

Informed consent atau Persetujuan Tindakan Medis sangat penting sehingga para dokter harus selalu melaksanakan sebaikbaiknya agar tuntutan hukum dari pihak pasien dapat dihindari. Jika seorang dokter tidak memperoleh persetujuan tindakan kedokteran yang sah, maka dampaknya adalah bahwa dokter tersebut akan dapat mengalami masalah, baik dari sisi hukum pidana, hukum perdata, maupun pendisiplinan.

\section{D aftar Pustaka}

Isfandyarie, Anny. M alpraktek dan Resiko Medik dalam Kajian Hukum Pidana. Jakarta: Prestasi Pustaka Publisher, 2005

Kerbala, Husein. Segi-segi Etis dan Yuridis Informed Consent, Jakarta: Pustaka Sinar Harapan, 2000

Guwandi, J. Informed Consent \& Informed Refusal, Jakarta: Fak. Kedokteran UI, 2006

Konsil Kedokteran Indonesia, M anual Persetujuan Tindakan Kedokteran, Jakarta: Konsil Kedokteran Indonesia, 2006

Loqman, Loebby. Tinjauan Hukum Pidana Terhadap Hubungan Tenaga Kesehatan D engan Konsumen/Pasien, Surabaya: 2000 
A driana Pakendek

Pabidang, Siswanto. "Pentingnya Informed Consent", Tabloid BIDI, (10 September 2004)

Komalawati, Veronika. Peranan Informed Consent dalam Transaksi Terapeutik Suatu Tinjauan Yuridis, Persetujuan Dalam Hubungan D okter dan Pasien. Bandung: Citra A ditya Bakti, 1999 